\title{
UNIVERSITY OF PITTSBURGH ADMINISTRATION AND FACULTY OF THE SCHOOL OF LAW
}

WILliam M. CARTER, JR., Dean and Professor of Law. B.S., Bowling Green State University; J.D., Case Western Reserve University.

KEVIN DEASY, Associate Dean of Students and Associate Professor of Legal Writing. B.A., Pennsylvania State University; M.S.W., J.D., University of Pittsburgh.

ANTHONY C. INFANTI, Senior Associate Dean for Administration and Special Projects and Professor of Law. B.A., Drew University; J.D., University of California, Berkeley; LL.M., New York University.

VINCENT O. JOHNSON, Director of Administration. B.A., Harvard University; M.B.A., Waynesburg University. CHARMAINE McCALL, Assistant Dean for Admissions and Financial Aid. B.A., M.B.A., University of Pittsburgh. LORI E. McMASTER, Director of Professional and Career Development. B.A., Allegheny College; J.D., University of Pittsburgh.

JEFFRIE W. MIRACLE, Director of Constituent Relations. B.A., Brigham Young University; M.Ed., Ph.D., University of Pittsburgh.

\section{FACULTY AND LIBRARIANS}

JESSIE ALLEN, Assistant Professor of Law. B.F.A., New York University; J.D., Brooklyn University; J.S.D., Columbia University.

CHAZ P. ARNETT, Visiting Assistant Professor of Law. B.A., Morehouse College; J.D., Harvard University. KEVIN D. ASHLEY, Professor of Law. B.A., Princeton University; J.D., Harvard University; M.A., Ph.D., University of Massachusetts.

ELENA A. BAYLIS, Associate Professor of Law. B.A., University of Oregon; J.D., Yale University.

DEBORAH L. BRAKE, Professor of Law and Distinguished Faculty Scholar. B.A., Stanford University; J.D., Harvard University.

RONALD A. BRAND, Chancellor Mark A. Nordenberg University Professor, Distinguished Faculty Scholar, and Director of the Center for International Legal Education. B.A., University of Nebraska; J.D., Cornell University.

DOUGLAS M. BRANSON, W. Edward Sell Chair in Business Law. B.A., University of Notre Dame; J.D., Northwestern University; LL.M., University of Virginia.

BENJAMIN E. BRATMAN, Associate Professor of Legal Writing. B.A., University of Washington; J.D., Vanderbilt University.

TERESA K. BROSTOFF, Director of the Legal Writing Program and Professor of Legal Writing. B.S., J.D., University of Pittsburgh

TOMAR NICOLE BROWN, Assistant Clinical Professor of Law. B.A., Denison University; J.D., Case Western Reserve University.

WILLIAM J. BROWN, Professor Emeritus of Law. B.A., Seton Hall University; LL.B., Catholic University of America; LL.M., Yale University; Certificate in International Business Law, City of London College.

JOHN M. BURKOFF, Professor of Law. A.B., J.D., University of Michigan; LL.M., Harvard University.

NANCY M. BURKOFF, Associate Dean for Academic Affairs and Associate Professor of Legal Writing. A.B., University of Michigan; J.D., University of Pittsburgh.

PAT K. CHEW, Judge J. Quint Salmon and Anne Salmon Chair. A.B., Stanford University; J.D., M.Ed., University of Texas.

CHARLES C. COHEN, Professor of Practice. A.B., Dartmouth College; J.D., University of Michigan.

WILliam A. CONGELIO, Visiting Clinical Professor of Law. B.A., California University of Pennsylvania; M.P.A., Carnegie Mellon University; J.D., Duquesne University.

DANSHERA CORDS, Distinguished Visiting Professor of Law. B.A., University of Washington; J.D., Seattle University; LL.M., New York University.

MARY CROSSLEY, Professor of Law. B.A., University of Virginia; J.D., Vanderbilt University.

VIVIAN CURRAN, Professor of Law and Distinguished Faculty Scholar. B.A., University of Pennsylvania; Ph.D., J.D., Columbia University.

RICHARD DELGADO, Distinguished Professor Emeritus of Law. A.B., University of Washington; J.D., University of California, Berkeley.

THE HON. JUDITH K. FITZGERALD, Professor of Practice. B.S., J.D., University of Pittsburgh.

ISSN 0041-9915 (print) 1942-8405 (online) • http://lawreview.law.pitt.edu 
HARRY MARSHALL FLECHTNER, Professor of Law. A.B., M.A., J.D., Harvard University.

CYRIL A. FOX, jr., Professor Emeritus of Law. A.B., College of Wooster; J.D., University of Pittsburgh.

LAWRENCE A. FROLIK, Professor of Law and Distinguished Faculty Scholar. B.A., University of Nebraska; J.D., LL.M., Harvard University.

DAVID J. GARROW, Research Professor of History and Law. B.A., Wesleyan University; M.A., Ph.D., Duke University.

JASMINE B. GONZALES ROSE, Assistant Professor of Law. B.A., University of Oregon; J.D., Harvard University. HAIDER ALA HAMOUDI, Associate Dean of Research Faculty Development and Associate Professor of Law. B.S., Massachusetts Institute of Technology; J.D., J.S.D., Columbia University.

ROBERT BERKLEY HARPER, Professor Emeritus of Law. B.S., J.D., University of Pittsburgh.

DAVID A. HARRIS, Professor of Law and Distinguished Faculty Scholar. B.A., Northwestern University; J.D., Yale University; LL.M., Georgetown University.

ARTHUR D. HELLMAN, Sally Ann Semenko Endowed Chair. B.A., Harvard University; J.D., Yale University.

BERNARD J. HIBBITTS, Professor of Law. B.A., Dalhousie University; M.A., Carleton University; B.A., M.A., Oxford University; LL.B., Dalhousie University; LL.M., University of Toronto; LL.M., Harvard University.

SUSANNA M. LEERS, Electronic Research and Technology Services Librarian. B.A., Columbia University; M.A., Clark University; M.L.I.S., M.L.S., M.S.L., University of Pittsburgh.

MICHAEL LEWYN, Visiting Associate Professor of Law. B.A., Wesleyan University; J.D., University of Pennsylvania; LL.M., University of Toronto.

JULES LOBEL, Bessie McKee Walthour Endowed Chair. B.A., New York University; J.D., Rutgers University. WILliAM V. LUNEBURG, JR., Professor Emeritus of Law. B.A., Carleton College; J.D., Harvard University. GRANT MacINTYRE, Assistant Clinical Professor of Law. B.S., Cornell University; J.D., University of Pittsburgh.

MICHAEL J. MADISON, Professor of Law and Faculty Director of the Innovation Practice Institute. B.A., Yale University; J.D., Stanford Law School.

MARGARET M. MAHONEY, Professor Emerita of Law. B.A., LeMoyne College; J.D., University of Michigan.

MARTHA M. MANNIX, Co-Director of Clinic Programs and Clinical Associate Professor of Law. B.A., University of Vermont; J.D., University of California, Hastings.

FRANCIS BARRY McCARTHY, Professor Emeritus of Law. A.B., Stonehill College; J.D., Boston College; LL.M., Columbia University.

ALAN MEISEL, Professor of Law and Psychiatry; Dickie, McCamey \& Chilcote Professor of Bioethics; and Director of the Center for Bioethics and Health Law. B.A., J.D., Yale University.

MARK A. NORDENBERG, Chancellor Emeritus of the University and Distinguished Service Professor of Law. B.A., Thiel College; J.D., University of Wisconsin.

PETER B. OH, Professor of Law. B.A., Yale University; J.D., University of Chicago.

PATRICIA A. RONCEVICH, Acquisitions/Serials Librarian. B.A., M.L.S., M.S., University of Pittsburgh.

THOMAS ROSS, Professor of Law. B.A., J.D., University of Virginia.

RICHARD HARRY SEEBURGER, Professor Emeritus of Law. A.B., Dickinson College; LL.B., LL.M., Harvard University.

KAREN SHEPHARD, Information Services Librarian. B.A., Grove City College; M.L.I.S., University of Pittsburgh.

MARC B. SILVERMAN, Acting Director of the Barco Law Library. B.F.A., Ohio University; M.L.S., M.A., University of Pittsburgh.

ANN SINSHEIMER, Professor of Legal Writing. B.A., M.A., University of Michigan; J.D., University of Pittsburgh; Ph.D., Carnegie Mellon University.

MATIANGAI SIRLEAF, Assistant Professor of Law. B.A., New York University; M.A., University of Ghana (Legon); J.D., Yale University.

STELLA L. SMETANKA, Clinical Professor Emerita of Law. B.A., Carlow College; J.D., University of Pittsburgh. SALLIE SMITH, Cataloging/Systems Librarian. B.S., Villa Maria College; M.L.S., Syracuse University; M.S.L., University of Pittsburgh.

JEAN STEFANCIC, Research Professor Emerita of Law. B.A., Maryville College; M.A., University of San Francisco. ALICE L. STEWART, Clinical Instructor of Law. B.S.B.A., Robert Morris University; J.D., Duquesne University.

LINDA TASHBOOK, Foreign, International and Comparative Law Librarian. B.S., Texas Woman's University; M.L.S., J.D., University of Pittsburgh.

GEORGE H. TAYLOR, Professor of Law. B.A., Brown University; M.A., University of Chicago; J.D., Harvard University.

ISSN 0041-9915 (print) 1942-8405 (online) • http://lawreview.law.pitt.edu 
JUDITH A. TEETER, Visiting Instructor of Law. B.A., University of Wisconsin; J.D., Boston University; Master's Certificate in Conflict Resolution, Duquesne University.

DAVID THAW, Assistant Professor of Law. B.S., B.A., University of Maryland; M.A., Ph.D., J.D., University of California, Berkeley.

SHEILA I. VÉLEZ MARTÍNEZ, Clinical Assistant Professor of Law. B.A., J.D., University of Puerto Rico. RHONDA WASSERMAN, Professor of Law. A.B., Cornell University; J.D., Yale University.

\section{AFFILIATED FACULTY}

KAREN CLAY, Associate Professor of Economics and Public Policy, Heinz School of Public Policy and Management, Carnegie Mellon University; Affiliated Professor, School of Law. B.A., University of Virginia; Ph.D., Stanford University.

ROBERT M. HAYDEN, Professor, Department of Anthropology, School of Arts and Sciences; Affiliated Professor, School of Law. B.A., Franklin and Marshall College; M.A., Syracuse University; J.D., Ph.D., State University of New York at Buffalo.

KENNETH M. LEHN, Samuel A. McCullough Professor of Finance, Katz Graduate School of Business; Affiliated Professor, School of Law. B.A., Waynesburg College; M.A., Miami University; Ph.D., Washington University. JEFFREY J. SHOOK, Assistant Professor, School of Social Work; Affiliated Assistant Professor, School of Law. B.A., Grinnell College; J.D., American University; M.S.W., Ph.D., University of Michigan.

\section{ADJUNCT FACULTY}

KEVIN C. ABBOTT, Director of the Energy Law \& Policy Institute and Adjunct Professor of Law. B.A., Indiana University of Pennsylvania; J.D., University of Pittsburgh.

SARA BURHAN ABDULLAH, Adjunct Professor of Law. J.D., LL.M., University of Pittsburgh; L.L.B., University of Sulaymania, Iraq.

RODNEY R. AKERS, Adjunct Professor of Law. B.A., University of Virginia; J.D., Harvard University.

CARRIE L. ALLMAN, Adjunct Professor of Law. B.A., Ohio Wesleyan University; J.D., University of Pittsburgh.

LYNN J. ALSTADT, Adjunct Professor of Law. B.S., B.A., J.D., University of Pittsburgh.

ALAN S. BAUM, Adjunct Professor of Law. B.S., Syracuse University; J.D., Ohio Northern University.

JACLYN M. BELCZYK, Adjunct Professor of Law. B.A., J.D., University of Pittsburgh.

C. ALLEN BLACK, JR., Adjunct Professor of Law. B.A., University of Alabama; Ph.D., University of Newcastle (Australia); J.D., University of Pittsburgh.

PAUL D. BOAS, Adjunct Professor of Law. B.A., J.D., University of Pittsburgh.

ALISON BONEBRAKE, Adjunct Professor of Law. B.A., Shippensburg University; M.P.A., University of Pittsburgh. THE HON. EDWARD J. BORKOWSKI, Adjunct Professor of Law. B.A., J.D., Duquesne University; M.S.W., University of Pittsburgh.

EDUARDO H. BOZZO, Adjunct Professor of Law. B.A., National School of Commerce (Buenos Aires, Argentina); J.D., University of Argentina.

DANIEL H. BREAN, Adjunct Professor of Law. B.S., Carnegie Mellon University; J.D., University of Pittsburgh. ROBERT MARC BRENNER, Adjunct Professor of Law. A.B., Stanford University; J.D., Yale University. CHRISTOPHER S. CHANNEL, Adjunct Professor of Law. B.A., West Virginia Wesleyan College; J.D., College of William and Mary.

JAMES P. COLETTA, Adjunct Professor of Law. B.A., J.D., University of Pittsburgh.

JULIE R. COLTON, Adjunct Professor of Law. B.A., Gannon University; J.D., University of Pittsburgh.

TIMOTHY CONBOY, Adjunct Professor of Law. B.A., Allegheny College; J.D., University of Pittsburgh.

JAMES V. CORBELLI, Adjunct Professor of Law. B.A., University of Maryland; J.D., University of Pittsburgh.

MARY NELL CUMMINGS, Director for the Graduate Certificate Program in Health Care Compliance and Adjunct Professor of Law. B.A., University of Arizona; J.D., University of Buffalo.

STEPHANIE DANGEL, Executive Director, Innovation Practice Institute and Adjunct Professor of Law. B.S., B.A./M.A., University of Pennsylvania; B.A., University of Oxford; J.D., Yale University.

ROBERT E. DAPPER, JR., Adjunct Professor of Law. B.A., Georgetown University; J.D., University of Pittsburgh.

ELLIOT DATER, Adjunct Professor of Law. B.A., J.D., University of Michigan.

CLAUDIA DAVIDSON, Adjunct Professor of Law. B.A., State University of New York (Buffalo); J.D., Rutgers University (Newark).

MARSHALL L. DAYAN, Adjunct Professor of Law. B.A., University of Georgia; J.D., Antioch University.

ISSN 0041-9915 (print) 1942-8405 (online) • http://lawreview.law.pitt.edu 
CHARLES A. De MONACO, Adjunct Professor of Law. B.A., University of Notre Dame; J.D., Ohio Northern University.

CECILE C. M. DESANDRE, Adjunct Professor of Law. Baccalaureate A2, The Sorbonne, Paris.

STEVEN A. DIAZ, Adjunct Professor of Law. B.A., San Francisco State University; J.D., Santa Clara University.

LOUIS A. DiNARDO, Adjunct Professor of Law. B.S., Pennsylvania State University; J.D., Duquesne University.

MATTHEW R. DIVELBISS, Adjunct Professor of Law. B.A., Grove City College; J.D., University of Pittsburgh.

ADAM S. ENNIS, Adjunct Professor of Law. B.S., University of Pittsburgh; J.D., Yeshiva University.

THOMAS J. FARRELL, Adjunct Professor of Law. B.A., Yale University; J.D., New York University.

RALPH G. FISCHER, Adjunct Professor of Law. B.S., Case Western Reserve University; J.D., University of Pittsburgh.

THE HON. D. MICHAEL FISHER, Adjunct Professor of Law. B.A., J.D., Georgetown University.

SUSAN FRIETSCHE, Adjunct Professor of Law. A.B., Bryn Mawr College; J.D., Temple University.

LINDSAY GALVIN, Adjunct Professor of Law. B.S., University of Pittsburgh; J.D., Duquesne University.

MICHAEL GEORGE, Adjunct Professor of Law. B.A., Bowling Green University; J.D., Duquesne University.

JOHN P. GISMONDI, Adjunct Professor of Law. B.A., J.D., University of Pittsburgh.

JOHN WAGNER GIVENS, Adjunct Professor of Law. B.S., Georgetown University; M.A., University of California, Berkeley; D. Phil., University of Oxford.

BRET GROTE, Adjunct Professor of Law. B.A., Washington and Lee University; J.D., University of Pittsburgh.

HARRY J. GRUENER, Adjunct Professor of Law. B.A., J.D., University of Pittsburgh.

K. MARK HALL, Adjunct Professor of Law. B.S., Michigan State University; J.D., University of Pittsburgh.

JOHN F. HAMMOND, Adjunct Professor of Law. A.B., Harvard College; M.St., Oxford University; J.D., Cornell University.

KEVIN C. HARKINS, Adjunct Professor of Law. B.A., Pennsylvania State University; J.D., University of Pittsburgh. CRAIG S. HERYFORD, Adjunct Professor of Law. B.F.A., The Ohio State University; J.D., Duquesne University.

LEO N. HITT, Adjunct Professor of Law. B.A., J.D., University of Pittsburgh; LL.M., New York University.

JOSEPH S. HORNACK, Adjunct Professor of Law. A.B., Miami University; J.D., Rutgers, The State University of New Jersey.

KENNETH J. HOROHO, JR., Adjunct Professor of Law. B.S., St. Francis College; J.D., Duquesne University.

THE HON. PHILIP A. IGNELZI, Adjunct Professor of Law. B.S.B.A., University of Dayton; J.D., University of Pittsburgh.

JOHN E. IOLE, Adjunct Professor of Law. B.A., J.D., University of Pittsburgh.

IRA M. KAROLL, Adjunct Professor of Law. B.A., Yeshiva University; J.D., Northwestern University.

STEPHEN R. KAUFMAN, Adjunct Professor of Law. B.A., Allegheny College; J.D., Harvard University.

ADAM F. KELSON, Adjunct Professor of Law. B.A., University of Pennsylvania; J.D., Boston University.

MILES A. KIRSHNER, Adjunct Professor of Law. B.A., George Washington University; J.D., University of Pittsburgh.

GEORGE KONTOS, Adjunct Professor of Law. B.A., J.D., University of Pittsburgh.

JAMES E. KOPELMAN, Adjunct Professor of Law. B.A., J.D., University of Pittsburgh.

DANIEL KOVALIK, Adjunct Professor of Law. B.A., University of Dayton; J.D., Columbia University.

SCOTT A. LANE, Adjunct Professor of Law. B.A., James Madison University; J.D., West Virginia University.

THE HON. BETH A. LAZZARA, Adjunct Professor of Law. B.A., J.D., University of Pittsburgh.

LAWRENCE M. LEBOWITZ, Adjunct Professor of Law. B.A., University of Pennsylvania; J.D., University of Pittsburgh.

THE HON. LISA PUPO LENIHAN, Adjunct Professor of Law. B.A., J.D., University of Pittsburgh.

RICHARD C. LEVINE, Adjunct Professor of Law. B.A., J.D., University of Pittsburgh.

PENINA K. LIEBER, Adjunct Professor of Law. B.A., M.A., J.D., University of Pittsburgh.

ALEXANDER H. LINDSAY, JR., Adjunct Professor of Law. B.A., Washington and Jefferson College; J.D., University of Pittsburgh.

BLAINE A. LUCAS, Adjunct Professor of Law. B.A., University of Pittsburgh; J.D., University of Virginia.

KEVIN P. LUCAS, Adjunct Professor of Law. B.A., Fordham University; J.D., University of Michigan.

JOHN PATRICK LYDON, Adjunct Professor of Law. B.A., Allegheny College; J.D., University of Pittsburgh.

BEVERLY WEISS MANNE, Adjunct Professor of Law. B.A., J.D., University of Pittsburgh.

JASON W. MANNE, Adjunct Professor of Law. B.S., State University of New York; J.D., M.B.A., M.A., Dr. PH,

University of Pittsburgh.

LISA ZEIDNER MARCUS, Adjunct Professor of Law. B.A., Duke University; J.D., Columbia University.

ISSN 0041-9915 (print) 1942-8405 (online) • http://lawreview.law.pitt.edu 
LISA A. MARTINELLI, Adjunct Professor of Law. B.Ph., J.D., University of Pittsburgh; M.A., Duquesne University. JASON E. MATZUS, Adjunct Professor of Law. B.A., Gettysburg College; J.D., University of Pittsburgh.

REGIS M. McCLELLAND, Adjunct Professor of Law. B.A., J.D., Duquesne University.

JOHN W. McILVAINE, III, Adjunct Professor of Law. B.S., Pennsylvania State University; J.D., Pepperdine University.

WILLIAM McKENDREE, Adjunct Professor of Law. B.A., University of Pittsburgh; M.A., J.D., Duquesne University,

LAURA A. MEADEN, Adjunct Professor of Law. B.A., Case Western Reserve University; J.D., University of Pittsburgh.

REID P. MEYER, Adjunct Professor of Law. B.S., Pennsylvania State University; J.D., University of Pittsburgh.

MAX F. MILLER, Adjunct Professor of Law. B.A., University of Pennsylvania; J.D., University of Pittsburgh; M.B.A., Kellogg School of Management.

J. W. MONTGOMERY, III, Adjunct Professor of Law. B.A., University of Virginia; J.D., College of William and Mary.

DEBORAH D. OLSZEWSKI, Adjunct Professor of Law. B.A., J.D., University of Pittsburgh; M.A., Edinboro State College.

DAVID R. OVERSTREET, Adjunct Professor of Law. B.S., Pennsylvania State University; J.D., Villanova University.

JON R. PERRY, Adjunct Professor of Law. B.A., Pennsylvania State University; J.D., Duquesne University.

LINDA PINGITORE, Adjunct Professor of Law. B.S., J.D., University of Pittsburgh.

WILLIAM C. PRICE, Adjunct Professor of Law. B.S.B.A., J.D., University of Pittsburgh.

J. MATTHEW PRITCHARD, Adjunct Professor of Law. B.S., Carnegie Mellon University; J.D., University of Pittsburgh.

JAMES A. PROZZI, Adjunct Professor of Law. B.A., J.D., University of Pittsburgh.

JEFFREY A. RAMALEY, Adjunct Professor of Law. B.A., University of Pittsburgh; J.D., Duquesne University.

STEPHIE-ANNA K. RAMALEY, Adjunct Professor of Law. B.S., University of Richmond; M.S., Virginia Commonwealth University; J.D., Duquesne University.

ROBERT B. RAMSEY, III, Adjunct Professor of Law. B.A., University of Delaware; J.D., St. Louis University.

DAVID J. ROSENBERG, Adjunct Professor of Law. B.A., Connecticut College; J.D., University of Pittsburgh.

MICHAEL H. ROSENZWEIG, Adjunct Professor of Law. B.A., J.D., University of Pittsburgh.

JOHN S. ROZEL, Assistant Professor of Psychiatry and Adjunct Professor of Law. A.B., M.D., Brown University; M.S.L., University of Pittsburgh.

STEPHANIE WINER SCHREIBER, Adjunct Professor of Law. B.A., Kent State University; J.D., University of Pittsburgh.

STEPHANIE L. SCIULLO, Adjunct Professor of Law. B.A., J.D., University of Pittsburgh.

JOSEPH W. SELEP, Adjunct Professor of Law. B.A., Indiana University of Pennsylvania; J.D., Ohio Northern University.

MATTHEW E. SHAMES, Adjunct Professor of Law. B.A., University of Pennsylvania; J.D. University of Pittsburgh. LARRY A. SILVERMAN, Adjunct Professor of Law. B.A., University of Pittsburgh; J.D., Duquesne University.

JENNIFER A. SMOKELIN, Adjunct Professor of Law. B.S.E., University of Pennsylvania; J.D., University of Pittsburgh.

MARCY SMOREY-GIGER, Adjunct Professor of Law. B.S., Westminster College; M.Sc., J.D., Duquesne University. STEVEN M. STADTMILLER, Adjunct Professor of Law. B.B.A., University of Notre Dame; J.D., University of Pittsburgh.

JOHN STEMBER, Adjunct Professor of Law. B.A., Ohio University; J.D., University of Pittsburgh.

NATALYA STEPANOVA-SIPPER, Adjunct Professor of Law. J.D., Tashkent State Law Institute; M.L., University of Pittsburgh.

EDWARD VAN STEVENSON, JR., Adjunct Professor of Law. B.A., Kentucky State University; J.D., University of Kentucky.

JOHN STINSON, Adjunct Professor of Law. B.A., Radford University; M.A., Bowling Green State University; J.D., University of Toledo; LL.M., Goethe Universitaet Frankfurt am Main (Germany).

JAN C. SWENSEN, Adjunct Professor of Law. B.S., J.D., University of Pittsburgh.

STEPHEN C. TANZILLI, Adjunct Professor of Law. B.S., Duquesne University; J.D., University of Pittsburgh.

THE HON. DAVID B. TORREY, Adjunct Professor of Law. A.B., West Virginia University; J.D., Duquesne University.

ISSN 0041-9915 (print) 1942-8405 (online) • http://lawreview.law.pitt.edu 
EMILY E. TOWN, Adjunct Professor of Law. B.A., American University; J.D., University of Pittsburgh. CHATÓN T. TURNER, Adjunct Professor of Law. B.A., University of Virginia; J.D., University of South Carolina. JAMES S. URBAN, Adjunct Professor of Law. B.A., University of Pittsburgh; J.D., Duquesne University. ELIZABETH F. BJERKE VAN NOSTRAND, Adjunct Professor of Law. B.A., J.D., Tulane University. JAMES M. VAN NOSTRAND, Adjunct Professor of Law. B.A., University of Northern Iowa; J.D., University of Iowa; M.A., State University of New York at Albany; LL.M., Pace University.

THE HON. CHRISTINE WARD, Adjunct Professor of Law. B.A., Washington and Jefferson College; J.D., University of Pittsburgh.

PETER M. WATT-MORSE, Adjunct Professor of Law. B.A., Carleton College; J.D., Northwestern University.

HEATHER WEINER, Adjunct Professor of Law. B.B.A., East Tennessee State University; J.D., Syracuse University.

PATRICIA HARRINGTON WYSOR, Legal Writing Center Director. B.A., Wheaton College; M.Ed., M.F.A., University of Pittsburgh.

THE HON. JOHN A. ZOTTOLA, Adjunct Professor of Law. B.A., J.D., University of Pittsburgh.

\section{ADMINISTRATIVE STAFF}

SARAH BARCA, Administrative Coordinator. B.A., Robert Morris University.

CORI BEGG, Director of Communications and Marketing. B.F.A., West Virginia University; M.P.W., Chatham University.

STEPHEN M. CONWELL, Financial Manager. B.S.B.A., Robert Morris College; B.S.I.S., University of Pittsburgh, CPA, CGMA.

LuANN M. DRISCOLL, Office Manager and Director of the Document Technology Center.

KIM GETZ, Director of Information Technology. B.S., M.S., Robert Morris University.

PAULA HOPKINS, Pitt Legal Services Incubator Director. B.A., J.D., The Ohio State University.

MEME JEFFRIES, Director of Financial Aid and Assistant Director of Admissions. B.S., Pennsylvania State University; M.Ed., University of Pittsburgh.

BETH T. LIBERATORE, Registrar.

ALEXANDRA LINSENMEYER, Director of Admissions. A.B., The College of William and Mary; M.Ed., The George Washington University.

ROCHELLE R. McCAIN, Director of Public Interest and Government Relations. B.A., University of Chicago; J.D., University of Houston.

JAMES MENTZER, Assistant Director, J.D. Advantage Careers. B.A., Westminster College; J.D., University of Akron.

RICHARD G. THORPE, Executive Director of the Center of International Legal Education. A.B., University of Chicago; Ph.D., Princeton University; J.D., Yale University.

SARAH WEISSMAN, Assistant Director, Private Sector Careers. B.A., University of Pittsburgh; J.D., Duquesne University.

ROBERT G. WIBLE, Director of Academic Success and Bar Exam Services. B.A., Waynesburg College; J.D., Duquesne University.

ISSN 0041-9915 (print) 1942-8405 (online) • http://lawreview.law.pitt.edu 